\title{
ON LEUCOZONIA NASSA
}

\author{
by EVELINE and ERNST MARCUS
}

(with 2 plates)

Four families of stenoglossan prosobranchs were studied in our Department, thaisids and buccinids by Edmund H. Smith, M. A., columbellids and olivids by ourselves. The present paper contains the description of a fasciolariid, Leucozonia nassa (Gmelin, 1791), frequent at the Base of Research, Bay of the Flamengo, which belongs to the Oceanographic Institute of the University of São Paulo. There we could work thanks to the Director of the Institute, Dr. Ingvar Emilsson, and the Head of the Base, Dr. Edmundo Nonato, to whom we are very much indebted.

\section{NAME, RANGE, OCCURRENCE}

Leucozonia cingulifera (Lamarck, 1816) is a synonym of Voluta nassa Gmelin, 1791 (Abbott 1955, p. 241). Turbinella brasiliana d:Orbigny ( 1841 , p. 449) was described as different from nassa by absence of keel, weak nodules, wanting whitish band, 3 columellar folds, and yellowish aperture. These characters are variable and do not justify specific separation. The nodules, up to 11 in number on the body whorl, are distinct in our specimens, and so they are in d'Orbigny's figure 17 on plate 77 . The keel is weak in our shells, and the whitish band often absent or indistinct. The folds are frequently 4 , as in typical nassa. The aperture is either whitish or yellowish. At first sight it seems that brasiliana can be maintained as a stibspecific name, because d'Orbigny's and our material have no spine cr dentiform tubercle (Fischer 1887, p. 617) on the outer lip. But a Brazilian, hence geographically segregated, subspecies is not characterized by the absence of this spine, as is shown by Perry and Schwengel's figure $(1955$, pl. 35, f. 239) of a snail from Western Florida without 
any spine. Also Keen $(1958$, p. 416) calls the tooth on the outer lip "weak to almost wanting in the type of Leucozonia", i. e., nassa.

The range of Leucozonia nassa extends from Florida through the West Indies and along the coasts of the Gulf of Mexico (Texas, Bank of Campeche) and the Caribbean Sea (Curaçao) to Brazil, southwards to the Bay of Guaratuba, Paraná (Gofferjé, 1950, p. 245) . Perhaps the species attains its southern limit here, because it is not common in the littoral of Paraná (1. c.), contrary to the farther northern coast of Brazil (Souza Lopes \& Alvarenga 1955, p. 174).

On the coast of São Paulo the snails live on boulders and rocks in the intertidal zone. During low tide they often hide in caves on the underside of the boulders or in the wet sand around their foot. The snails feed by means of the long proboscis on vermetids (Petaloconchus), barnacles, and polychaetes. The intestine of many snails contained great numbers of setae, e. g. of terebellids and sabellariids (ailerons of Phragmatopoma). Compared with Thais haemastoma they are very sluggish in movement; at night however, they are more active, as Mr. Edmund H. Smith observed in October 1960 near São Scbastião.

Among the several hundreds of snails which we have handled two snails had a shell of $49 \mathrm{~mm}$ length, generally the biggest were $40 \mathrm{~mm}$.

\section{EXTERNAL CHARACTERS AND MANTLE CAVITY}

The soft parts are red, only the fore end of the foot is orange. The operculum is black; it is oval and acute at the apical nucleus. The eyes lie in the middle of the outer side of the tentacles. In one snail the left tentacle bore 3 eyes of almost equal size with the single right eye, one beside the other. Possibly this multiplication occurred during regeneration (Simroth 1907, p. 960). The siphon is short, bears a broad band of cilia on its borders and is supplied by nerves emerging from a big ganglion which lies at the base of the siphon among the fibres of the siphonal retractor.

The foot is short and rounded behind. Its anterior border is bilabiate and notched in the middle. The furrow is deep; the anterior pedal glands (Graham 1957, p. 141) arranged in packets discharge 
to this groove on its whole breadth without a special duct. Behind the furrow lie conspicuous secondary ganglia formed by pedal nerves. The ventral pedal gland (1. c., p. 142) or female moulding gland is lccated in the anterior third of the sole as a rather smooth-walled sac. The pedal sucker of muricacean Stenoglossa (Fretter, 1946), also present in Drupa (Edmund H. Smith), does not occur in Leucozonia rassa, nor in other Buccinacea, as Buccinum, Cantharus (Edmund $\mathbf{H}$. Smith), Pisania (id.), and the Columbellidae that we examined.

As the apical angle of the shell is $55-60^{\circ}$, the mantle cavity is intermediate between narrow and wide. Clusters of gland cells lie under the ciliated epithelium of the upper mantle edge in the connective tissue. The inferior mantle border is much less differentiated, also its nerves are thinner. The anterior region of the upper edge contains a blood lacuna and another is situated inwards to the glands. The principal blood-supply of the mantle is provided by a sinus on the cuter, the shell-side, of the mantle. Hence a respiratory function of the ceiling of the pallial cavity is not suggested by the distribution of blood spaces in $L$. nassa, contrary to some columbellids examined by us and the phasianellid Tricolia affinis.

The hypobranchial gland consists of high cells. On the roof of the mantle cavity it extends on the right side, from the tip of the crenidium to the fundus, where ceiling and floor coalesce. The gland occupies also part of the floor leaving free the vestibule and the rectum.

Under the genital aperture and the anus a ventral band of cilia runs to the mantle edge. Cilia occur also in front of the ventral hypobranchial lobe, but cease before they attain the anterior border. Another ventral ciliated strip leads the excretion from the renal slit forwards to the region underlain by the visceral ganglia. As this streak lies under the left side of the gill the particles transported by it can be taken over by the cilia that carry the sediments dropped from osphradium and gill to the right side. These cilia form a broad rand under osphradium and ctenidium; they begin on the left side of the pallial floor and end under the female aperture where the current they produce merges into the principal outgoing one. The inhalant current is brought about by the cilia of the borders of the siphon and the branchial ones. 
The ctenidium contains 285 leaflets and is $2,7 \mathrm{~mm}$ broad. The csphradium has 84 left and 108 right leaflets; it is $1,9 \mathrm{~mm}$ broad. viz. the left filaments 0,7 , the right 0,9 , and the axial ganglion 0,3 $\mathrm{mm}$ broad. Compared with the columbellids that we examined the osphradium is relatively small.

\section{CENTRAL NERVOUS SYSTEM (Fig. 1)}

The ganglia which are reddish in living snails lie all very near together as in the fasciolariid studied by Bouvier (1887, p. 254). Compared with Buccinum (ibid., p. $256 \mathrm{ff}$.) the nerve ring of Leucozonia nassa is even more concentrated, as the cerebro-pedal and pedal-pleural connectives are shorter, and the buccal ganglia (cc) not only in close contact with the cerebral ganglia as in Buccinum but also touching one another.

The pedal ganglia (ea) are long and are the biggest elements. Their anterior margins are subdivided into several cones as in the columbellids, and as in these the right ganglion is more dorsal than the left one. The anterior border of the foot is richly supplied with nerves. The cephalic aorta (ao) rises in front of the buccal ganglia and runs forwards over the pedal commissure.

The cerebral commissure is twice as high as broad. The pleural ganglia (eu) lie under the cerebral ones (er), the left pleural ganglion is considerably farther ventral. The siphonal branch of its thick pallio-siphonal nerve $(s n)$ forms a secondary ganglion as in columbellids.

The left pleural ganglion is broadly connected with the subintestinal ganglion (iu) which lies under the right pleural ganglion. As in other Buccinacea the right zygoneury established by the union of the subintestinal with the right pleural ganglion is highly developed. A strong pallio-parietal nerve (wi) runs to the right side. It comes from the limit between right pleural and subintestinal ganglion. The supraintestinal ganglion (ai) is apposed to the right pleural ganglion without an external connective. Two visceral ganglia, a big bilobed and a smaller simple one, lie quite near to one another at the hind end of the anterior body cavity (Fig. 5, va). A third accessory ganglion is a little in front of these ganglia. 


\section{ALIMENTARY TRACT}

The radula (Fig. 2) begins with colourless teeth in the oldest rcws, while those of the newest series are brownish. The rhachidian tooth has 3 denticles. The lateral teeth have up to 7 denticles, the innermost of which is biggest, bears a minute point and ends with an inward curve.

The entrance of the proboscis sheath is fixed by muscles, but a great part of it follows the base of the proboscis when the proboseis is extruded. About 4 pairs of protractors of the proboscis sheath originate on the floor of the mantle cavity, and two thick bundles of retractors originating laterally on the wall insert behind them. The highly contractile proboscis is pinkish and attains, when fully extended, nearly twice the length of the shell. The buccal artery is thick.

The two pink salivary glands are completely separate. Their ducts are tucked into the lateral folds of the oesophagus which they join ectally from the nerve ring, between the fore end of the pharynx of Leiblein and the base of the proboscis. The salivary ducts open from both sides into the buccal cavity at the level of the fore end of the radula.

As in muricids, columbellids and the buccinid Pisania (Edmund F. Smith) the pharynx of Leiblein of Leucozonia nassa is pyriform. The effect of torsion, however, as known of muricids (Graham 1941, r. 17), is not recognizable in L. nassa, nor in the other mentioned Buccinacea. An orange ring around the anterior end of the pharynx of Leiblein is the mucous pad of other Stenoglossa (Graham 1941, p. 6, 12; Marcus 1959 , p. 125-26), and as in these, the oesophagus enters the organ with a conical strongly ciliate valve. According to Amaudrut (1898, p. 237) there is no pyriform pharynx of Leiblein in certain fasciolariids (Fúsininae). Also in the Buccinidae, Pisania has this pyriform organ, while Buccinum (Dakin 1912) and Cantharus (Edmund H. Smith) have not. In the Olividae, it is present in Oliva and Lintricula, not in Olivella. The nerve ring surrounds the oesophagus behind the pharynx of Leiblein.

The brown gland of Leiblein emits its duct from the anterior end. The duct is lined with high gland cells all around, while the gland itself is, as in other Buccinacea (Graham 1941, p. 17) less. 
secretory than in the Muricacea. In young snails $(12 \mathrm{~mm})$ the gland of Leiblein is tubular, in full-grown specimens its anterior part is wide and folded. The long and slender posterior end (Fig. 5, ei) enters the cephalic blood sinus ( $\mathrm{si}$ ), whence it extends into the afferent vessel of the accessory renal system (vi). Here it ends with a thinwalled ampulla under the renal epithelium. In our descriptions of columbellids whose elongated gland of Leiblein also attains the kidney we mention some similar long glands of Leiblein in the Steringlossa; also in Pisania it extends into the kidney (Edmund $\mathrm{H}$. Smith) .

A reduced vestige of torsion occurs in the part of the mid-oesophagus that lies between the nerve ring and the entrance of the duct of the gland of Leiblein. The mid-oesophagus is theoretically (Graham 1941, p. 13) the expanded dorsal food channel, while the gland of Leiblein is the glandular ventral part of the oesophagus. It was stripped off from the dorsal part (ibid., p. 16), when the development of the long proboscis elongated the anterior oesophagus and pulled the mid-oesophagus through the nerve ring. The site of the attachment of the glandular ventral part is marked by a small group of unciliate cells. These appear at the level of the entrance of the gland of Leiblein, mid-dorsally in consequence of torsion. In transverse sections of this level the scar-like mark forms a shallow groove between the longitudinal folds of the mid-oesophagus, and this groove can be traced in the forwards following sections descending to a more ventral position. In Leucozonia nassa it cannot be followed to its mid-ventral place in front, because the shape of the oesophagus becomes irregular, where it is compressed by the nerve ring.

The wall of the posterior oesophagus is folded longitudinally. The organ is brown and fastened to the bottom of the body cavity by at muscle ring as in Oliva and Olivancillaria (Marcus, 1959, p. 126, 129 ). Behind this point the oesophagus widens, and the number of folds increases. Their height is irregular, but one of them, situated to the right of the middle, may be a little higher. Short behind the entrance of the oesophagus (Fig. 3, e) into the stomach lies the aperture (1) of the right duct of the digestive gland. The food string (oo) is transported over 6 high transverse folds which characterize the fundus of the stomach. To the left of the fundus extends the intestinal groove 
(ir) accompanied on the inner side by the major typhlosole (rm) . In the pyloric region the groove is bordered by the major and the minor typhlosole ( $\mathrm{mi}$ ). The beginning of this region approximately coincides with the aperture (1) of the left duct of the digestive gland. An elaborate transverse folding on the right side of the stomach may perhaps represent a posterior sorting area (sa) as in Nassarius (Graham 1949, p. 749, f. 22). The food string which is gradually transformed into a faecal string is passed to the pyloric region, where mucus produced by gland cells of the typhlosoles cements it to a faecal rod. No caecum nor a gastric shield are developed in the tubular stomach of this evidently purely carnivorous stenoglossan.

The typhlosoles continue beyond the pyloric region into the intestine (Fig. 8, i) which runs rather straight (Fig. 7, i). It contains bristles and teeth of polychaetes in the examined snails. If it is empty, its lumen may be star-shaped in transverse section, due to longitudinal folds, or more or less distinctly crescent-shaped.

\section{RENAL ORGAN (Figs. 4, 5)}

The dark reddish brown kidney belongs to the type that Perrier (1889, p. 250) found in his Sténoglosses Pycnonephridiens. The renal cavity communicates with that of the pericardium (ca) by a short ciliated duct (Fig. 8, re). Farther in front the renal wall and the pericardium are separated by the intervening nephridial and blood gland (oa). At this level the urinary chamber (ui) opens into the mantle cavity ( $p$ ) by a wide slit-like aperture (ni) .

The inner wall or floor of the kidney is a delicate, simple epithelium without glands. The roof or outer wall is extended into folds, the bigger of which, the principal system (f), hide the smaller folds of the accessory system (vi). From the renal sinus under the floor of the kidney muscular afferent renal vessels rise, pass through the floor and the renal cavity and attain the ridges of the principal folds. The epithelium of these folds consists of glandular renal cells and ciliated cells at the summits. Connective tissue containing some muscle fibres supports the epithelium and surrounds the narrow blood spaces supplied by the branches of the afferent vessels. From these internal blood spaces the blood is collected on the outer surface of the kidney in efferent vessels. These run towards the right renal border, then 
along the hypobranchial gland (y) and through this to the afferent bianchial vessel.

The afferent vessel of the accessory system originates from the cephalic sinus which contains the prolonged posterior end of the gland of Leiblein (ei). The vessel has thin walls and runs through the renal cavity near the wall, where it branches into the accessory folds (vi). These contain a net of connective tissue, minute blood lacunae, plentiful amoebocytes, and acidophilous crystalloids (Cuénot 1914, p. 281). Evidently the efferent vessels lead the blood from the accessory system chiefly through the nephridial and blood gland (oa) to the auricle $(\mathrm{au})$.

\section{MALE REPRODUCTIVE ORGANS}

The dark red testis lies apically over the greenish digestive gland. The silky white efferent duct coils on the columellar side of the visceral mass. This testicular part of the male duct stores sperm, hence functions as seminal vesicle. Its epithelium is rather high, without cilia, and contains yellowish concretions; sperm absorption, as was verified in Littorina and several Stenoglossa (Fretter 1941, p. 175 ff.), was not observed in the sectioned 2 males. The following part of the male duct, the renal efferent duct, is straightened, ciliate, and its muscular coat is thick. A little in front of the fundus of the pallial cavity, in the region of the visceral ganglia and the extension of the hind end of the gland of Leiblein into the secondary afferent vessel of the kidney, muscular strands and vessels connect the renal efferent duct with diverticula of pericardium and kidney. Pervious ducts or pores are not developed.

The following pallial spermiduct (Fig. 6) runs in a bulge of loose connective tissue without any communication with the mantle cavity. The epithelium of this prostatic part is ciliate, thrown into folds and pierced by the ducts of glands. These penetrate the parietal nuuscles of the prostatic spermiduct, and the long orange clusters of the glands lie embedded into the richly developed vesicular connective tissue which surrounds the pallial male duct. The latter begins dorsally to the suture of the pallial cavity, beside the intestine. From the level of the anus forwards the spermiduct runs along the floor of the pallial cavity, near to its right border and shines orange-yellow 
through the mantle. Under the mantle edge the duct curves to the left and enters the penis.

At rest, the penis is turned backwards. Sometimes its threadlike white tip extends far into the pallial cavity, sometimes it is completely retracted into the red base of the copulatory organ.

\section{FEMALE REPRODUCTIVE ORGANS (Figs. 7, 8)}

The dark red ovary supplied by white spotted vessels covers the apical halves of the whorls; full-grown ovocytes contain up to $30 \mu$. long yolk granules. The thin oviduct is lined with a low, simple epithelium in its ovarian section and runs between kidney $(k)$ and intestine (i). Farther outwards the renal section (io) is characterized by a folded epithelium whose high cells have basal nuclei. This renal part begins at the level of the origin of the aorta from the ventricle. Still farther ectally the typical cilia of the renal oviduct appear, and there are more longitudinal folds. This section is connected with the pericardium (ca) by a broad and folded duct (no) which ends with a ciliated knob beside the outlet of the renopericardial communication (re). The gonopericardial duct has a layer of strong circular muscles near the pericardium. Also the buccinid Pisania janeirensis has a wide gono-pericardial duct (Edmund $H$. Smith).

Ectally to the gonopericardial duct the ciliated renal oviduct enters the albumen gland (az). This red organ has the form of a backwards turned U. Its lumen is compressed and slightly folded; the epithelium is ciliated as in the muricids and buccinids studied by Fretter (1941, p. 184, 190-92); the underlying gland cells are grouped in clusters and stain blue. The lumen of the albumen gland opens broadly into that of the capsule gland $(\mathrm{cn})$. Where these two sections cf the pallial oviduct communicate with one another, the ventral sperm channel of the capsule gland merges into the ciliated duct of the seminal receptacle (zs). This consists of many tubular pouches which lie on the inner or columellar side of the visceral coil, around the anterior end of the albumen gland. In the pouches the sperms lic in parallel bundles; no sign of sperm ingestion was seen.

The salmon coloured capsule gland $(\mathrm{cn})$ is rather long and shows its differently staining regions already in the living snail. In 
sections the ventral channel contained sperms. Between the capsule gland and the hypobranchial gland runs the intestine. Beside the rectum courses the most ectal part of the female duct. the vestibule (v). This winding organ, almost as long as the capsule gland, but centracted in Fig. 7, has a folded lumen lined with a rather low epithelium which bears long cilia and does not contain glands. The folds are highest in the innermost region of the vestibule, farther outwards the lumen becomes narrower, duct-like, and the muscular coat still thicker. A little in front of the anus (ar) the vestibular cluct curves and forms a small papilla on whose tip (u) it opens.

A bursa copulatrix (ur) is dorsally annexed to the distal part of the vestibular duct. It projects from the muscle mantle of the vestibule. The bursal epithelium is high (60-180 $\mu)$, not ciliated, but stuffed with granules. In many dissected snails and some sections the bursa contains brown amorphous masses, no recognizable sperms.

\section{EGGS}

On January 1, 1961 we found a snail whose shell was $35 \mathrm{~mm}$ in length laying egg capsules in a concavity of a rock, possibly an empty sea urchin hole, just emerging from low tide level. There were already 16 capsules attached to the ceiling of the hole laid in 4 rows of 4 capsules each. These are flattened bottles (Fig. 9), 7 $\mathrm{mm}$ high, $3,5 \mathrm{~mm}$ broad with a basal $1 \mathrm{~mm}$ long stalk. The blunt distal end of the capsule is plane and has a circular thinned area near one side. Each transparent capsule contained 40-50 dark pink cggs, about $0,4 \mathrm{~mm}$ in diameter. In our laboratory where Leucozonia nassa always behaves extremely inactive, the female did not lay further capsules; also the previously produced eggs did not develop over the stage of 4 blastomeres over night at a temperature of $30^{\circ}$ C., so they were preserved. As in many gastropods the polocytes are big. The question whether the species has nurse-eggs must be left open; in each capsule a number of eggs did not cleave at all, but this may have been due to the warmth.

More or less similar egg capsules of Fasciolariidae were figured by Risbec (1932, p. 369), Habe (1944, p. 196, f. 5), and Perry and Schwengel (1955, figs. 352-354). 


\section{CONCLUSIONS}

Leucozonia nassa is a typical stenoglossan snail. Its radula with richly dentate lateral plates whose size by far surpasses that of the Ihachidian tooth assigns the species to the Buccinacea. The indications of Thiele's diagnosis of the family Fasciolariidae (1931, p. 326) were, for the most part, verified by the preceding study . The eyes, however, do not lie at the base of the tentacles, but higher upwards, and the cucts of the salivary glands do not pass through the nerve ring, but attain the anterior oesophagus farther in front.

There are many more fossil fasciolariids than recent ones. The range of the family is restricted principally to warm waters. Many species live below the intertidal zone, in which competition among animals is most intense. These facts suggest that the family on the whole recedes. Of course, this general impression cannot be confirmed by every single species, e. g., the present one which is frequent in the intertidal zone of our coast.

As many Stenoglossa Leucozonia nassa combines specialized and primitive traces, but the former overweigh the latter. The nervous system is highly concentrated; the stomach is of an advanced type without caecum and gastric shield; the kidney is compact; and the spermiduct is completely closed without any communication with the mantle cavity. Primitive features are the pyriform pharynx of Leiblein and the broad gono-pericardial duct of the female. The mixture of primary and secondary characters in many Stenoglossa explains Thiele's statement (1935, p. 1095): "the families belonging to the Stenoglossa are all more or less intimately related with one another".

Compared with Thais haemastoma the present species is more frequent in somewhat sheltered niches. Its shell is strong and thick, so that it might also withstand the surf which sweeps over the mentioned muricacean with great force. Possibly the foot of Leucozonia rassa is too small to warrant the snail an unfailing holdfast on fully exposed boulders. On the other hand, L. nassa hides in the wet sand around the rocky outcrops at low tide and lives also where the worms of Phragmatopoma build their tubes of the sand carried by the waves. Under both conditions the inhalant current of Leucozonia nassa will contain many sand grains, but the richly developed cilia of the floor of the pallial cavity evidently provide perfect sanitation. 


\section{RESUMO}

Leucozonia nassa (Gmelin 1791) é o nome válido de $L$. cingulifera (Lamarck, 1816). O nome de Turbinella brasiliana d'Orbigny, 1841, não se justifica, nem subespecificamente, pois foi introduzido baseado em caracteres variáveis da concha.

Leucozonia nassa é frequiente nas rochas próximas da Base de Pesquisas do Instituto Oceanográfico de São Paulo, 14 quilômetros a oeste de Ubatuba. Ocorre na zona das marés, principalmente em nichos ecológicos algo abrigados da ressaca, talvez devido à pequenez do pé, o órgão de aderência. O caramujo alimenta-se de poliquetos, p. e. Phragmatopoma, cracas, e Petaloconchus (Prosobranchia, Vermetidae) por meio da sua tromba muito comprida, distensível e contractil. Locomove-se durante a noite mais que de dia e se esconde, nas horas da baixa-mar, freqüentemente, na areia molhada ao pé das rochas.

Da anatomia do sistema nervoso, estômago, rim, e duto masculino infere-se alta especialização de $L$. nassa dentro da superfamília Buccinacea, ao passo que a faringe de Leiblein, de configuração piriforme, e o largo duto gonopericardial na fêmea são caracteres primitivos. O efeito da torção vê-se no trecho do esôfago médio delimitado pela desembocadura do duto da glândula de Leiblein e o anel nervoso. Na diagnose da família Fasciolariidae (Thiele, 1931, p. 326), à qual Leucozonia pertence, duas passagens devem ser alteradas, a relativa a posição dos olhos, situados distalmente à base da espécie presente, e a que se refere aos dutos salivares que atingem o esôfago anteriormente ao anel nervoso e, destarte, não o atravessam.

\section{REFERENCES}

ABBOTT, R. Tucker, 1955 - American Seashells. XIV + 541 p., 40 pl. New York (D. van Nostrand).

AMAUDRUT, Alexandre, 1898 - La partie antérieure du tube digestif et la torsion chez les Mollusques Gastéropodes. Ann. sci. nat. Zool. sér. 8, v. 7, p. 1-291, pl. 1-10. Paris.

BOUVIER, E. L., 1887 - Système nerveux, morphologie générale et classification des Gastéropodes prosobranches. Ann. sci. nat. Zool. sér. 7, v. 3, p. 1510, pl. 1-19. Paris.

CUÉNOT, Lucien, 1914 - Les organes phagocytaires des Mollusques. Arch. Zool. expér. génér. v. 54, p. 267-305, pl. 10-13. Paris. 
DAKIN, William J., 1912 - Buccinum (The Whelk). L. M. B. C. Memoir 20, VIII + 115 p., 8 pl. London.

FiSCHER, P., 1887 - Manuel de Conchyliologie. XXIV + 1369 p., 23 pl. Paris (F. Savy).

FRETTER, Vera, 1941 - The genital ducts of some British stenoglossan prosobranchs. Journ. mar. biol. assoc. Unit. Kingd. v. 25, p. 173-211, 6 text-figs. Cambridge.

— 1946 - The pedal sucker and anal gland of some British Stenoglossa. Proc. malacol. Soc. v. 27 , p. 126-130, 2 text-figs. London.

GOFFERJE', Carlos N., 1950 - Contribuição à zoogeografia da malacofauna do litoral do Estado do Paraná. Arq. Mus. Paran. v. 8, p. 221-282, pl. 31-35. Curitiba (Brasil).

GRAHAM, Alastair 1941, The oesophagus of the stenoglossan prosobranchs. Pr. R. Soc. Edinb. v. 61, p. 1-23, 5 text-figs. Edinburgh and London.

— 1949, The molluscan stomach. Tr. R. Soc. Edinb. v. 61, pt. 3, p. 737778,24 figs. Edinburgh.

— 1957 - The molluscan skin, with special reference to prosobranchs. Proc. malacol. Soc. v. 32, p. 135-144. London.

HABE, Tadashige, $1944 \rightarrow$ On the eggs and development of Japanese marine gastropods (2). Shell Stud. Magazine v. 13, p. 194-201. Tokyo.

KEEN, A. Myra, 1958 - Sea Shells of Tropical West America. VIII + 626 p., $10 \mathrm{pl}$. University Press, Stanford, Cal.

MARCUS, Eveline and ERNESTO, 1959 - Studies on Olividae. Bol. Fac. Fil. Univ, Zool. no. 22, p. 99-188, 11 pl. São Paulo.

GRBIGNY, Alcide d', 1835-46 - Voyage dans l'Amérique Méridionale. Vol. 5, 3e partie: Mollusques. Atlas 1846. Paris et Strasbourg.

FERRIER, R., 1889 - Recherches sur l'anatomie et l'histologie du rein des Gastéropodes prosobranches. Ann. sci. nat. Zool. sér. 7, v. 8, p. 61-315, pl. 5-13. Paris.

FERRY, Louise M. and Jeanne S. SCHWENGEL, 1955 - Marine shells of the western coast of Florida. 318 p., 55 pl. Ithaca, N. Y. (Paleontological Research Institution).

RISBEC, Jean, 1932 - Note sur la ponte et le développement de Mollusques Gastéropodes de Nouvelle-Calédonie. Bull. Soc. Zool. France v. 57 n. 4, p. 358-374. Paris.

SIMROTH, Heinrich, 1896-1907 - Gastropoda Prosobranchia. Bronn, Kl. Ordn. v. 3, Abtlg. 2, VII + 1056 p., 63 pl. Leipzig (C. F. Winter).

SOUZA LOPES, Hugo de \& M. ALVARENGA, 1955 - Contribuição ao conhecimento dos Moluscos da ilha Fernando de Noronha. Bol. Inst. Oceanogr. v. 6 (1957), p. 157-196, 3 pl., 1 map. São Paulo.

THIELE, Johannes, 1931; 1935 - Handbuch der systematischen Weichtierkunde. VI + V, 1154 p., 897 text-figs. Jena (G. Fischer). 


\section{EXPLANATION OF LETTERS}
ai - supra-intestinal ganglion.
es - pleural ganglia.
au - aorta.
$f$ - principal folds of kidney.
$\mathbf{a}_{\bar{i}}$ - anus.
$\mathrm{i}$ - intestine.
au - auricle.
io - oviduct.
$\mathrm{a} z$ - albumen gland.
ir - intestinal groove.
b - ctenidium.
iu - subintestinal ganglion.
$\mathrm{ca}$ - pericardium.
k - kidney.
cc - buccal ganglia.
1 - apertures of digestive gland.
cn - capsule gland.
me - mantle.
e - oesophagus.
mi - minor typhlosole.
ea - pedal ganglia.
ni - renal aperture.
ei - gland of Leiblein.
nn - tentacle nerve.
er - cerebral ganglia.
no - gonopericardial duct.
oa - nephridial and blood gland. ui - urinary chamber.
on - osphradial-branchial nerve. ur - bursa copulatrix.
oo - food string.
p - pallial cavity.
re - renopericardial duct.
rm - major typhlosole
sa - sorting area.
si - blood space.
sn - pallio-siphonal nerve.
u - female aperture.
$\mathrm{v}$ - vestibule.
va - visceral ganglia.
ve - ventricle.
vi - acessory renal folds.
wi - right pallio-parietal nerve.
xn - penial nerve.
$\mathrm{y}$ - hypobranchial gland.
zs - seminal receptacle 
PLATES 


\section{PLATE 1}

Fig. 1 - Central nervous system.

Fig. 2 - Two rows of radula.

Fig. 3 - Stomach opened on dorsal side.

Fig. 4 - Heart and kidney.

Fig. 5 - Combined transverse section of renal region. 
E. \& E. MARCUS - LEUCOZONIA - PLATE 1
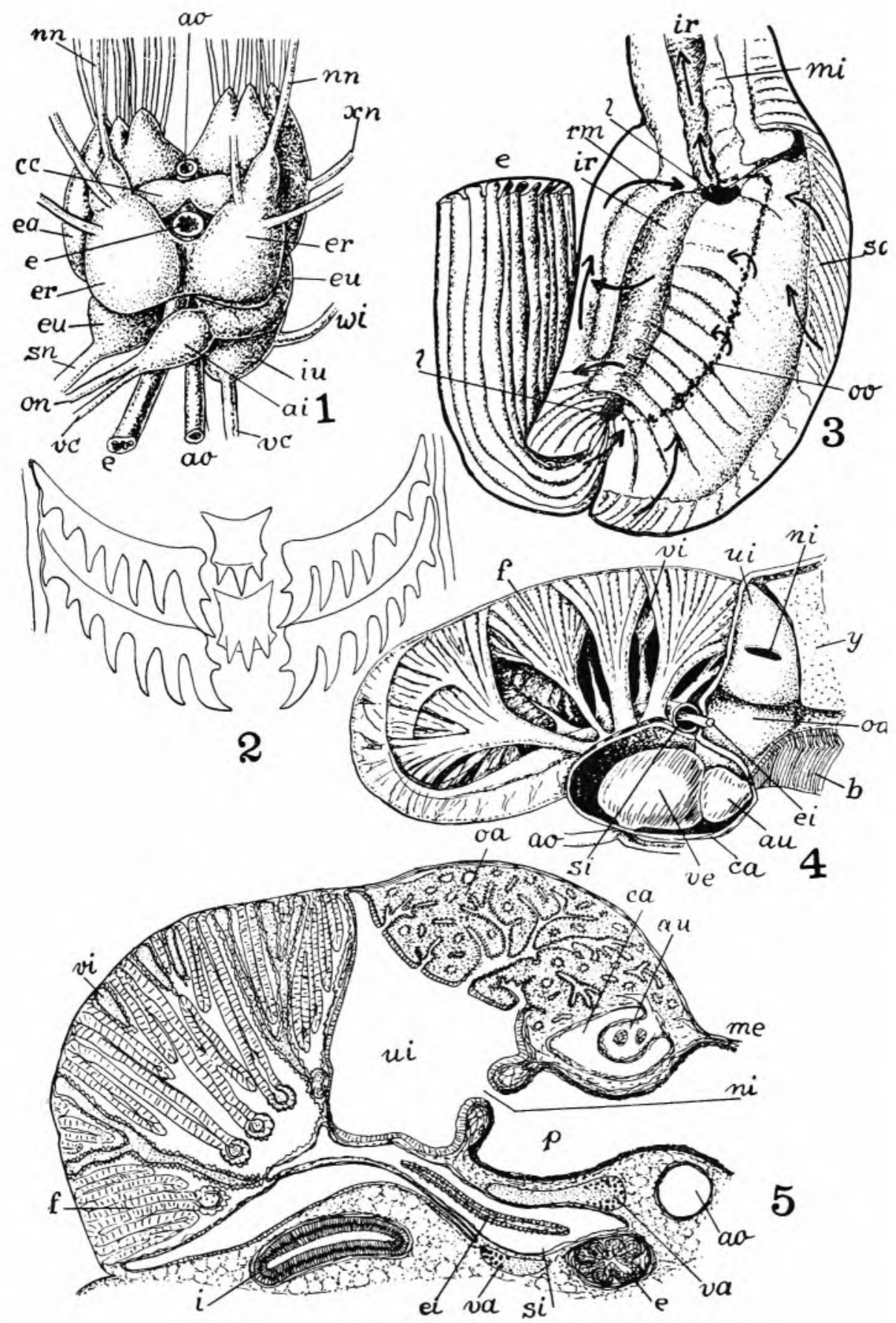


\section{PLATE 2}

Fig. 6 - Transverse section of prostatic part of sperm duct.

Fig. 7 - Female efferent organs.

Fig. 8 - Combined section of central region of female duct.

Fig. 9 - Egg capsules. 
E. \& E. MARCUS - LEUCOZONIA - PLATE 2
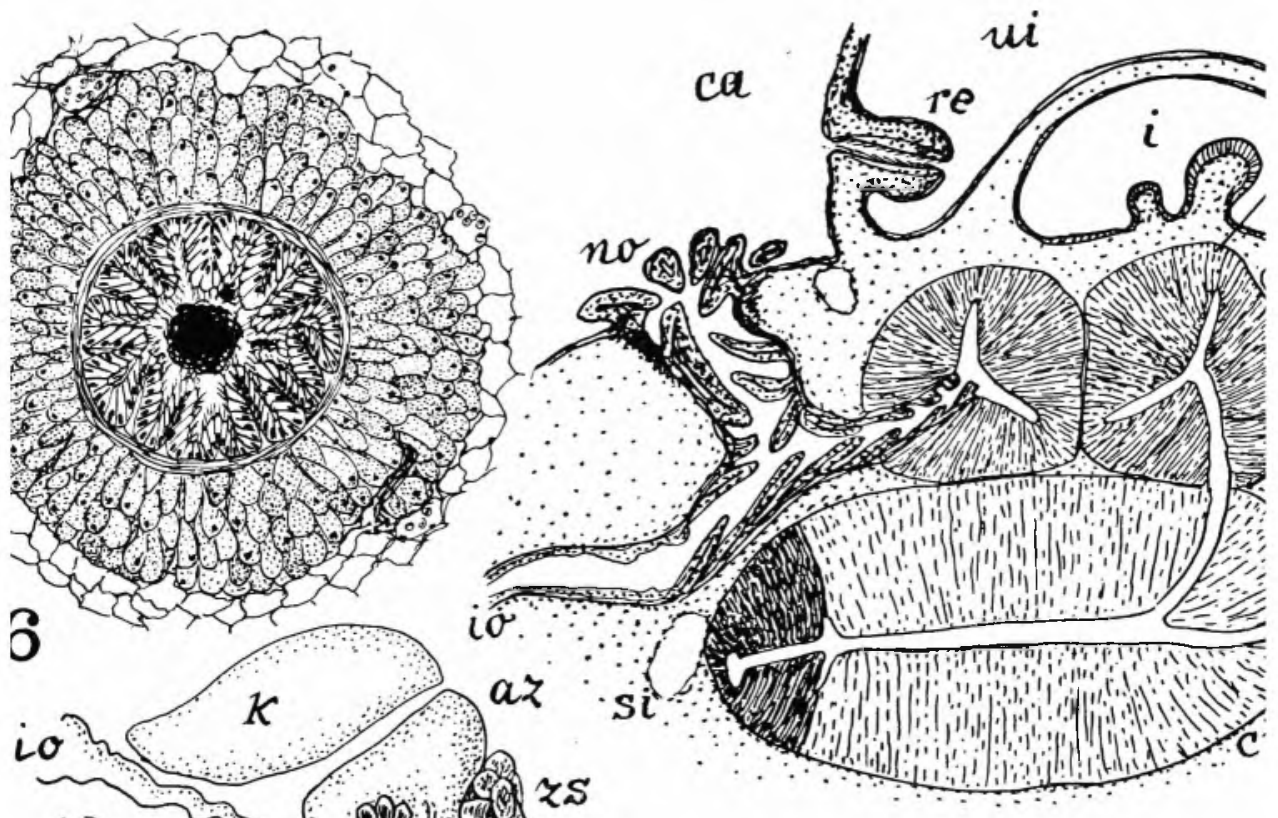

3
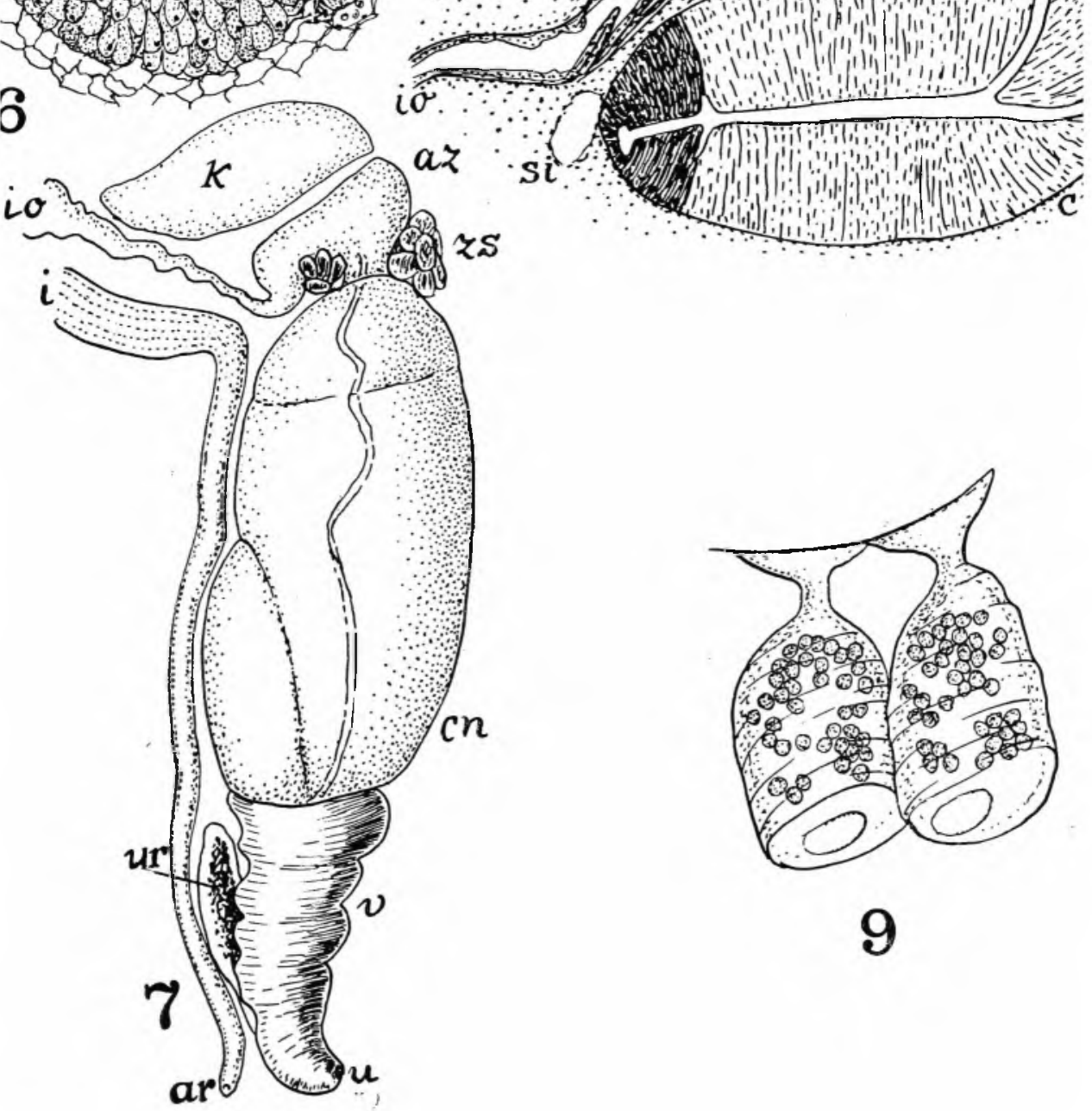
